
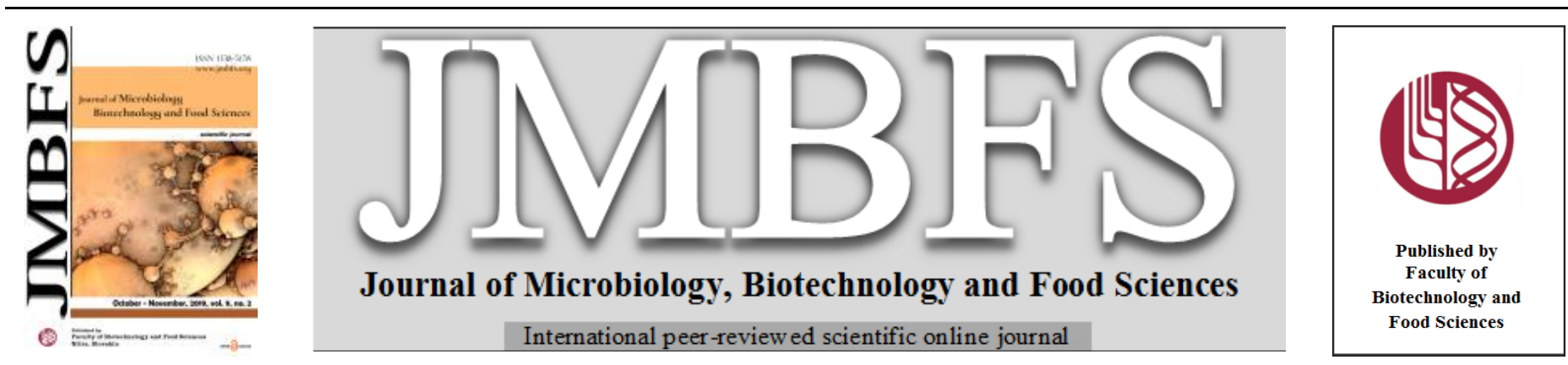

\title{
BIOCONVERSION OF CRUDE GLYCEROL INTO REUTERIN BY LACTOBACILLI ISOLATED FROM SILAGE
}

\author{
Marcela J. González*1, Jorge Olivera ${ }^{1}$, Pablo Chilibroste ${ }^{2}$, Stella Reginensi ${ }^{1}$ \\ Address(es): MSc. Marcela J. González, \\ ${ }^{\prime}$ Unidad de Tecnología de los Alimentos, Facultad de Agronomía, Garzón 780, Montevideo, Uruguay, + 59823547991. \\ ${ }^{2}$ Departamento de Producción Animal y Pasturas, Facultad de Agronomía, EEMAC, Paysandú, Uruguay.
}

*Corresponding author: marcejoan@gmail.com

doi: 10.15414/jmbfs.2019.9.2.174-178

\section{ARTICLE INFO}

Received 9. 8. 2018

Revised 22. 3. 2019

Accepted 25. 3. 2019

Published 1. 10. 2019

Regular article OPEN $\partial_{\text {ACCESS }}$

\begin{abstract}
Heterofermentative lactobacilli were isolated from sorghum and maize silage, and their ability to produce the antimicrobial compound reuterin (3-hydroxypropionaldehyde, 3-HPA) was investigated. Additionally, reuterin production from crude and partially purified biodiesel-derived glycerol was evaluated as an alternative to the utilization of these by-products. Only two out of 148 lactobacilli isolated produced reuterin in the presence of glycerol. The gene encoding a subunit of glycerol dehydratase was detected by PCR in isolates SO8 and SO23, identified as Lactobacillus reuteri by 16S rRNA gene sequence analysis. Levels of reuterin produced by these two isolates and strain L. reuteri DSM 17938, used as control, were different. For each bacteria, the amount of reuterin detected from biodiesel-derived glycerol was comparable with that obtained from aqueous solution of pure glycerol. Among silage isolates, $L$. reuteri SO23 yielded the highest levels of reuterin production. In addition, cell-free supernatants revealed inhibitory activity against silage spoilage microorganisms like spore-forming bacteria, yeast and mould. L. reuteri SO23 proved to be a valuable candidate for use of crude glycerol and its bioconversion to reuterin. Addition of glycerol together with reuterin-producing lactobacilli strains could represent a good alternative as silage biopreservant and help optimize profit in biodiesel production.
\end{abstract}

Keywords: Lactobacillus reuteri, reuterin, silage, biodiesel-derived glycerol

\section{INTRODUCTION}

Glycerol has become an abundant resource as by-product of the biodiese industry (Stelmachowski, 2011). The utilization of waste glycerol for fine chemical synthesis could reduce pollution and bring down the biodiesel production costs. A wide variety of microorganisms can utilize glycerol as substrate for the production of cell biomass and high value-added compounds through oxidative and reductive pathways. Microbial bioconversion of glycerol results in the synthesis of a variety of chemicals like 1,3-propanediol (1,3-PDO), dihydroxyacetone, citric acid, glyceric acid, 3-hydroxypropionaldehyde, succinic acid, erythritol, polyhydroxyalkanoates and other compounds (Dobson et al. 2012). Some lactic acid bacteria (LAB) belonging to the genus Lactobacillus produce the antimicrobial compound reuterin (3-hydroxypropionaldehyde or 3 HPA) during anaerobic metabolism of glycerol (Talarico and Dobrogosz, 1989; Vollenweider $\boldsymbol{e} \boldsymbol{t} \boldsymbol{a l}$., 2010). Bioconversion of crude glycerol by LAB into a compound with antimicrobial activity could lead to new biothecnological application for this waste product, and the development of new bioprotective microbial cultures.

The search for bioprotective cultures is a topic in development in many areas of microbiology, including silage microbiology. Silage is feedstuff produced by the fermentation of crop or forage under anaerobic conditions. As a result of watersoluble carbohydrate consumption mainly by LAB, lactic acid is produced and $\mathrm{pH}$ below 4 is achieved. One of the main problems that affect the nutritional quality and safety of silage is aerobic deterioration. Yeasts that degrade lactic acid in the presence of air trigger aerobic spoilage. In combination with mould development, silage becomes unstable and heats rapidly. Degradation of lactic acid increases $\mathrm{pH}$ values to levels that allow the development of less acid tolerant microorganisms, like spore-forming bacteria. Aerobic (Bacillus spp.) and anaerobic (Clostridium spp.) spore-forming bacteria increase the impact of spoilage by hydrolytic enzyme production and undesired fermentation. Aerobic spoilage is the major cause of reduced nutritional value of silage and increases the risk of development of potential pathogenic microorganisms frequently associated with silage like enterobacteria, Listeria spp. and Salmonella (Queiroz et al., 2018). In addition, moulds that develop in air-exposed silages may produce mycotoxins, which are detrimental to the health of humans and animals (Pahlow et al., 2003). Lactic acid bacteria, mainly Lactobacillus spp., are the most common biological additives used to preserve silage worldwide. Main effects of bacterial inoculants are preservation by acidification during storage, and prevention of aerobic spoilage of opened silos. A highly desirable attribute of silage bacterial inoculants, besides lactic acid production, is production of antimicrobial substances (Duniére et al., 2013).

Some LAB belonging to the genus Lactobacillus produce a non-protein antimicrobial compound, soluble in water, resistant to heat and stable over a wide $\mathrm{pH}$ range (2-8), known as reuterin (3-hydroxypropionaldehyde or 3-HPA) (Talarico et al., 1988; El-Ziney and Debevere, 1998). Reuterin is produced during anaerobic metabolism of glycerol as an intermediate step in the conversion of glycerol to 1,3-propanediol (Lüthi-Peng et al., 2002). Enzymes participating in this bioconversion pathway are under the control of the propanodiol ( $p d u)$ utilization operon (Morita et al., 2008). This low molecular weight compound is active against a wide range of Gram-positive bacteria such as Staphylococcus, Listeria, Clostridium and Bacillus, as well as Gram-negative like Escherichia coli, Yersinia, Shigella, Pseudomonas and Salmonella (Arqués et al., 2004; Axelsson et al., 1989; Bian et al., 2011; Cleusix et al., 2007; ElZiney and Debevere, 1998; Spinler et al., 2008). Reuterin also inhibits growth of several moulds and yeasts, including Candida albicans, Pichia sp., Kluyveromyces sp. (Tanaka et al., 2009; Martin et al., 2005), Aspergillus flavus (Axelsson et al., 1989) and Penicillium sp. (Martin et al., 2005). Some strains of Lactobacillus brevis, Lactobacillus buchneri, Lactobacillus collinoides, Lactobacillus coryniformis and Lactobacillus reuteri, excrete reuterin under anaerobic conditions (Schütz and Radler, 1984; Claisse and Lonvaud-Funel, 2000; Nakanishi et al., 2002; Gómez-Torres et al., 2014). These reuterinproducing Lactobacillus strains could be considered as potential bioprotective cultures, and some examples have been described. The application of these bacteria with glycerol generated a suitable environment for in situ production of reuterin, reaching adequate concentrations to control pathogens that may be present during the manufacture and storage of dairy products (Langa et al., 2013). In the same way, inoculation of $L$. coryniformis plus glycerol inhibited butyric fermentation and retarded yeast and mould growth, preventing rice straw ensiling spoilage (Tanaka et al., 2009).

Reuterin-producing Lactobacillus could be potential silage inoculants to control spoilage microorganisms and prevent butyric fermentation and aerobic spoilage. An additional challenge for this hypothesis is to explore alternative glycerol sources, like biodiesel-derived glycerol, for reuterin production. A modified strain of Lactobacillus diolivorans was able to produce high value C3 chemicals 
like 3-hydroxypropionialdheyde, 1,3-propanediol and 3-hydroxypropionic acid from crude glycerol (Lindlbauer et al., 2017). Other lactobacilli like $L$ delbrueckii, L. acidophilus, and $L$. plantarum can efficiently use biodieselderived glycerol as carbon source for biomass and energy production, but the reductive pathway involved in the synthesis of reuterin is not expressed in these bacteria (Rivaldi et al., 2013). The existence of microbial strains able to produce reuterin from crude glycerol prompted us to analize the potential of silage derived lactobacilli strains to convert biodiesel-derived glycerol into reuterin, with the future perspective of being used as silage inoculant. In this study, heterofermentative lactobacilli isolated from sorghum and maize silage were selected and evaluated for reuterin production using crude and partially purified biodiesel-derived glycerol as substrate.

\section{MATERIALS AND METHODS}

\section{Isolation and selection of reuterin-producing lactobacilli}

Sorghum (20) and maize (5) bag silage were obtained from different farms located in the South of Uruguay, in areas dedicated to dairy production. Silage samples were homogenized in a laboratory blender Stomacher 400 Circulator (Seward Ltd., Worthing, UK). Decimal dilutions were prepared in $9 \mathrm{~mL}$ of $0.1 \%$ of sterile peptone water, plated on Man Rogosa Sharpe agar (MRS, Oxoid Ltd, UK) and incubated at $37^{\circ} \mathrm{C}$ for $48 \mathrm{~h}$ under microaerophilic conditions using the Anoxomat MARK II gas exchange system (MART Microbiology B.B., the Netherlands). After incubation, up to five colonies per sample were picked randomly from the plate and purified by streaking on MRS agar. Phenotypic characterization was performed by routine laboratory test: colony morphology, catalase and oxidase test, and Gram staining. Only catalase and oxidase negative Gram-positive rod-shaped isolates were subcultured in MRS broth (Oxoid, UK) at $37^{\circ} \mathrm{C}$ for $24 \mathrm{~h}$. Inverted Durham tubes were used to visualize gas production. $\mathrm{CO}_{2}$ producing isolates were inoculated in $5 \mathrm{~mL}$ of MRS broth with glycerol (250 $\mathrm{mM}$ ) at $37^{\circ} \mathrm{C}$ for $24 \mathrm{~h}$. Then, cells were harvested by centrifugation at $10000 \mathrm{rpm}$ for $5 \mathrm{~min}$, suspended in $30 \mathrm{~mL}$ of an aqueous solution with $250 \mathrm{mM}$ glycerol and incubated for $3 \mathrm{~h}$ at $37^{\circ} \mathrm{C}$ under anaerobic conditions. After incubation, cell suspensions were centrifuged at $10000 \mathrm{rpm}$ for $20 \mathrm{~min}$ at $4^{\circ} \mathrm{C}$ and the supernatant was recovered and filtered $(0.2 \mu \mathrm{m}$ pore size; Sartorius Inc., California, USA) Compounds with carbonyl groups, presumptively reuterin, were detected in cellfree supernatants by microplate colorimetric method (see below). Inhibitory activity of cell-free supernatants was determined by disk diffusion assay. Briefly, $100 \mu \mathrm{L}$ of cell-free supernatant were pipetted onto filter paper disks (diameter 6 mm, Whatman, GE Health Care, NJ, USA) placed on Plate Count Agar (PCA, Oxoid, UK) plates previously inoculated with $100 \mu \mathrm{L}$ of an overnight culture of E. coli DH5a, used as indicator microorganism. This strain was cultured in Tryptic Soy Broth (TSB, Oxoid, UK) (an approximate concentration of $10^{4}$ cells). Clear zones around the disks (>2 $\mathrm{mm}$ ) after $24 \mathrm{~h}$ of incubation at $37^{\circ} \mathrm{C}$, were considered positives for inhibitory activity (Martin $\boldsymbol{e t}$ al., 2005).

\section{Determination of antimicrobial spectrum}

Disk difussion assay previously described was used to determine inhibitory activity of reuterin-producing isolates against species of spore-forming bacteria, moulds and yeasts. Cell-free supernatants were pipetted onto filter paper disks placed on agar plates previously inoculated with $100 \mu \mathrm{L}$ of an overnight culture of indicator microorganism. The following microorganisms, from our own culture collection, were used as indicators: Bacillus licheniformis UY132, Bacillus pumilus UY1030, Bacillus subtilis UY1067, Clostridium tyrobutyricum UY226.3, Clostridium sporogenes UY185.1, Penicillium sp. UY12, Candida sp. UY22.8 and Kluyveromyces sp. UY15.2. As well, inhibitory activity against sorghum silage homogenizate, containing natural occuring moulds and yeasts, was tested. Ten grams of silage were homogenizated with $90 \mathrm{~mL}$ of sterilized peptone-water $(1,0 \mathrm{~g} / \mathrm{L}$ peptone and $8,50 \mathrm{~g} / \mathrm{L} \mathrm{NaCl})$ in a laboratory blender Stomacher 400 Circulator (Seward Ltd., Worthing, UK) for 2 minutes at 260 rpm. Malt Extract Agar plates (MEA, Oxoid, UK) were inoculated with $100 \mu \mathrm{L}$ of silage homogenizate. Plates with disks, supernatants and bacterial indicators were incubated at $37^{\circ} \mathrm{C}$ for $48 \mathrm{~h}$. Bacillus spp. were grown in PCA medium and Clostridium spp. were grown in Reinforced Clostridium Agar (RCA, Oxoid, UK) under anaerobic conditions. Plates with yeast and mould cells, grown in MEA, were incubated at $27^{\circ} \mathrm{C}$ for $48 \mathrm{~h}$ and $120 \mathrm{~h}$, respectively. Finally, plates were examined for clear zones of inhibition around the disks (>2 mm). Inhibitory activity experiments were performed in duplicate.

\section{Reuterin production quantification}

Reuterin production was quantified by the typical ketone or aldehyde functional group assay described previously by Tokuyama et al. (2014) for methylglyoxal quantification, with modifications. Reuterin-producer $L$. reuteri DSM 17938 was included as positive control. Isolates were inoculated in $5 \mathrm{~mL}$ of MRS broth with glycerol $(250 \mathrm{mM})$ at $37^{\circ} \mathrm{C}$ for $24 \mathrm{~h}$. Cells were harvested by centrifugation at $10000 \mathrm{rpm}$ for $5 \mathrm{~min}$, resuspended in $30 \mathrm{~mL}$ of an aqueous solution with $250 \mathrm{mM}$ glycerol (Sigma Aldrich, $99.5 \%$ ) and incubated at $37^{\circ} \mathrm{C}$ under anaerobic conditions for $3 \mathrm{~h}$. Cells suspensions were previously adjusted when needed to $\mathrm{OD}_{600 \mathrm{~mm}}=1\left(\sim 10^{9} \mathrm{CFU} / \mathrm{mL}\right)$. Carbonyl compounds present in filtered cell-free supernatants were determined using a microplate colorimetric assay with 2,4-dinitrophenylhydrazine (2,4-DNPH) (Sigma Aldrich). The reaction mixture containing $200 \mu \mathrm{L}$ of supernatant and $67 \mu \mathrm{L}$ of $2,4-\mathrm{DNPH}$ solution $(0.1 \%$ 2,4-DNPH in $2 \mathrm{M} \mathrm{HCl})$ was incubated for $15 \mathrm{~min}$ at $30^{\circ} \mathrm{C}$, and then $333 \mu \mathrm{L}$ of $10 \% \mathrm{NaOH}$ was added. After 15 min incubation at room temperature, the presence of dinitrophenylhydrazone was determined by absorbance measurements $\left(\mathrm{A}_{544 \mathrm{~nm}}\right)$. One arbitrary unit (AU) was defined as the amount of dinitrophenylhydrazone required to increase one unit of $A_{544 \mathrm{~mm}}$ under the assay conditions. Reuterin production was determined considering that one mole of dinitropenylhydrazone can be synthesized per mole of reuterin. The assay was also performed by substituting the aqueous glycerol solution for crude glycerol $(50 \% \mathrm{w} / \mathrm{w}$ glycerol) and glycerol partially purified by splitting with $\mathrm{HCl}$ ( $70 \%$ w/w glycerol), adjusted to $250 \mathrm{mM}$ of available glycerol. Crude and partially purified glycerol were obtained as by-product from biodiesel production kindly provided by ALUR Alcoholes del Uruguay (Montevideo, Uruguay). All assays were performed in triplicate and the values were expressed as the mean \pm S.D. Statistical analysis was performed using analysis of variances ANOVA. Differences were considered statistically significant at $\mathrm{P}$ $<0.05$.

\section{PCR detection of glycerol dehydratase gene}

A polymerase chain reaction (PCR) method was conducted to detect the presence of $p d u C$ gene, encoding a subunit of glycerol dehydratase, the first enzyme in the reuterin formation pathway. Primers pduCF (5'CCTGAAGTAAAYCGCATCTT-3'), pduCR PdUCF GAAACYATTTCAGTTTATGG-3') and PCR conditions described by Walter $\boldsymbol{e}$ al. (2011) were used. L. reuteri DSM 17938 DNA was included as positive control. Preparation of genomic DNA was performed from bacterial overnight cultures in MRS broth, cells were harvested at 10,000 rpm for $5 \mathrm{~min}$ and DNA was purified using a Genomic DNA purification kit (Fermentas International Inc., USA) following the manufacturer's instructions. Purified DNA was suspended in $100 \mu \mathrm{L}$ TE buffer and used as template in amplification reactions. DNA concentration was determined using a NanoDrop 2000 spectrophotometer (Thermo Scientific Incorporation, Wilmington, DE, USA).

\section{Identification of selected reuterin-producing isolates}

A second PCR reaction was carried out to identify selected isolates at species level. Primers fD1 and rD1 were used to amplify a 1540 bp 16S rRNA gene fragment (Weisburg et al., 1991). PCRs were performed using an initial denaturation step at $94{ }^{\circ} \mathrm{C}$ for $7 \mathrm{~min}$, then 35 cycles of $94^{\circ} \mathrm{C}$ for $1 \mathrm{~min}, 56^{\circ} \mathrm{C}$ for 1 min and $72^{\circ} \mathrm{C}$ for $1 \mathrm{~min}$ and a final extension at $72^{\circ} \mathrm{C}$ for $10 \mathrm{~min}$. Amplified fragments were purified and sequenced by Macrogen Sequencing Service, Korea, using an ABI PRISM 3730XL capillary sequencer (Applied Biosystems, CA, USA). To identified the isolates obtained, DNA sequences were compared with the 16S ribosomal RNA sequence database from NCBI (National Center for Biotechnology Information), using the standard Nucleotide BLAST program (http://blast.ncbi.nlm.nih.gov/Blast.cgi).

\section{RESULTS AND DISCUSSION}

\section{Selection and identification of reuterin-producing isolates}

Most bacterial silage inoculants are composed by homofermentative and/or heterofermentative lactobacilli. Few heterofermentative Lactobacillus spp. are able to produce reuterin, and this ability is strain specific (Burgué et al., 2015). In the present work, from 25 samples of sorghum and maize bag silage, were obtained 148 isolates grown on MRS agar plates. A total of 30 isolates produced gas under anaerobic conditions in MRS broth and were considered as heterofermentative lactobacilli. Isolates were evaluated for their ability to produce carbonyl compounds, presumptively reuterin, under anaerobic conditions by a microplate colorimetric assay. Results are shown in Figure 1A. Positive results were detected in cell-free supernatants of only two isolates ( $\mathrm{SO} 8$ and SO23). A change of colour, owing to the formation of dinitrophenylhydrazone as an orange or red precipitate was visualized. $\mathrm{SO} 8$ and $\mathrm{SO} 23$ reuterin-producing isolates were obtained from two different sorghum silage samples. Phenotypic features of these two isolates corresponded to Gram positive, catalase and oxidase negative rods, able to metabolize glucose by the heterofermentative pathway. Most of these characteristics suggested that these isolates could belong to the genus Lactobacillus. The occurrence of reuterin-producing lactobacilli in sorghum and maize silage was low (two isolates out of 148). All silage analyzed were commercially inoculated with microbial additives, carriyng several LAB species. Nutrient competitive pressure between inoculated LAB and epiphytic crop bacteria may explain the scarce occurrence. Microplate colorimetric assay resulted in a simple, rapid and effective method that evidence at first glance the presence of reuterin in supernatants and was then used to quantify the concentration of this compound by spectrophotometry. Cell-free supernatants 
inhibitory activity on indicator microorganism E. coli DH5a was observed by disk difussion assay shown in Figure 1B. The production of an antimicrobial compound, presumed reuterin, by isolates $\mathrm{SO} 8$ and $\mathrm{SO} 23$ incubated in the presence of aqueous glycerol solution was then evidenced.

Genomic DNA of the two reuterin-producing isolates and control strain were used as templates in PCR reactions designed to amplify part of glycerol dehydratase $(p d u C)$ gene. A $122 \mathrm{bp}$ amplicon corresponding to a fragment of $p d u C$ gene, encoding a subunit of glycerol dehydratase, the first enzyme in the propanediol fermentation/reuterin formation pathway, was obtained for isolates SO8 and SO23, as well as for reference strain L. reuteri DSM 17938 (data not shown). Molecular screening for reuterin formation pathway enzymes encoding genes is not enough to ensure reuterin production. However, the determination of antimicrobial activity and the detection of ketone or aldehyde functional groups in the supernatant (Figure 1), suggest that isolates $\mathrm{SO} 8$ and $\mathrm{SO} 23$ could produce reuterin under assayed conditions and the amplified products could be related with its synthesis. To support this, a chemical characterization of the antimicrobial compound using additional analytical techniques, like HPLC should be done (Tokuyma et al., 2014).

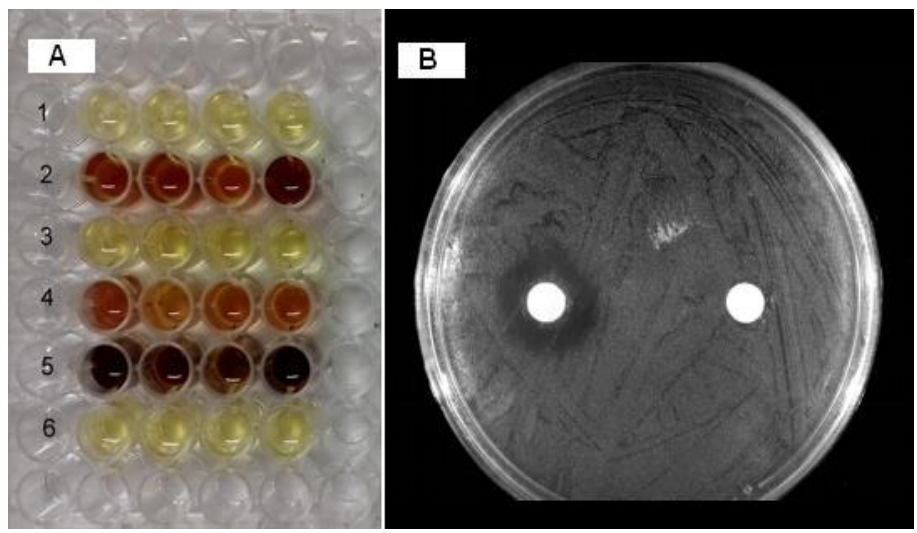

Figure 1 Reuterin-producing screening methodology. A. Colorimetric reaction for reuterin detection in cell-free supernatants in microtiter plates. Lane 5 positive control, lane 6: negative control, lanes 1 and 3: non reuterin-producing isolates, lanes 2 and 4: reuterin-producing isolates. B. Inhibitory activity assay using E. coli $\mathrm{DH} 5 \alpha$ as indicator microorganism.

Isolates $\mathrm{SO} 8$ and $\mathrm{SO} 23$ were identified as Lactobacillus reuteri by partial $16 \mathrm{~S}$ rRNA gene sequence analysis (GenBanK DNA sequence accession numbers: MH487823, MH487824). Several strains of $L$. coryniformis (Martin et al., 2005), L. collinoides (Sauvageot et al., 2000), L. buchneri, L. brevis (Schutz and Radler, 1984), and $L$. reuteri (Talarico et al., 1988) are able to produce antimicrobial substance reuterin. Most reuterin-producing strains reported in literature are $L$. reuteri strains. $L$. reuteri is not able to consume glycerol as sole carbon and energy source, because these bacteria don't express an enzyme with dihydroxyacetone kinase activity, required for channeling the glycerol into central carbon metabolism (Dishisha et al., 2014).

\section{Reuterin quantification and antimicrobial spectrum}

Reuterin concentration was determined in cell-free supernatants by the production of dinitrophenylhydrazone, measured spectrophotometrically. Reuterin production levels by L. reuteri $\mathrm{SO} 8$ and $\mathrm{SO} 23$ are shown in Figure 2. L. reuteri DSM 17938 strain was included as positive control. When aqueous glycerol solution was used as substrate, differences in reuterin production were observed among reuterin-producing isolates $(\mathrm{P}=0,005)$. DSM 17938 and isolate SO23 exhibited higher values compared to isolate SO8.

The quantification of reuterin included as first step the normalization of cell biomass previous to the incubation with glycerol. Then, the differences observed between isolates should be attributed to differences in the efficiency of glycerol conversion pathway, and not to the number of active cells. Glycerol uptake, enzymatic pathway imbalance and toxic accumulation of 3hydroxypropionialdheyde (reuterin), could be some of the reasons that explain the differences observed (Burgué et al., 2015, Vollenweider and Lacroix, 2004). Results indicate that although $\mathrm{SO} 8$ and $\mathrm{SO} 23$ were identified as L. reuteri, they correspond to two strains with different glycerol conversion capabilities.

Antimicrobial spectrum was evaluated using cell-free supernatants of SO8 and SO23 isolates. The supernatants exhibited a broad spectrum of inhibitory action against aerobic and anaerobic spore-forming bacteria (Table 1). Data showed that all tested strains were sensitive to reuterin by the presence of clear zones of inhibition around the disk (> $2 \mathrm{~mm})$. Bacillus and Clostridium species used for the inhibitory activity assay belongs to our laboratory culture collection and are natural occuring contaminants in dairy farm environment. Penicillum sp. and both yeasts tested were also inhibited. Additionally, a silage homogenizate containing natural occuring moulds and yeasts was challenged against reuterin containing supernatants. The inhibitory effect on this population was evident, limiting the growth of fungi and yeasts colonies around the disk (Figure 3) Sensitivity to reuterin of spore-forming bacteria and the inhibitory activity observed for natural occurring silage contaminants, set up a great expectation for the role of reuterin as silage biopreservant.

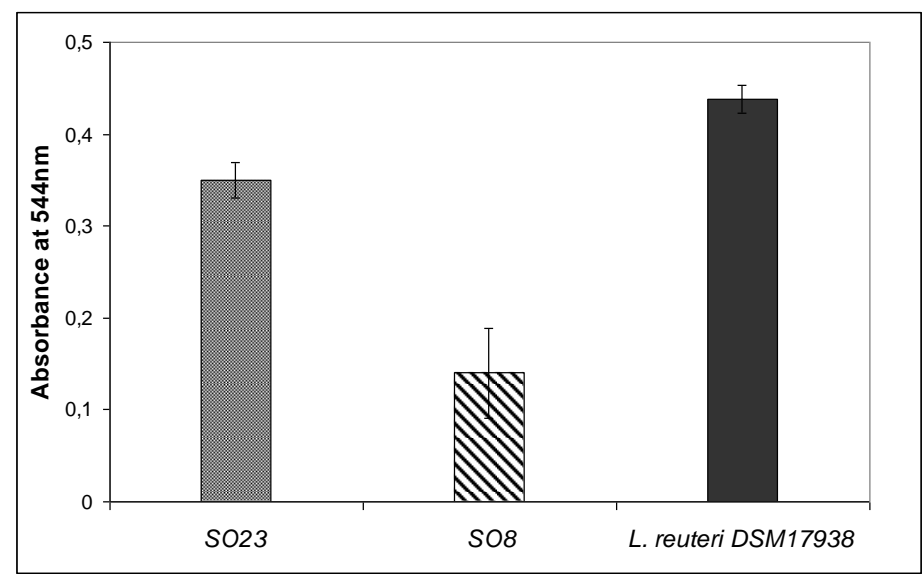

Figure 2 Reuterin production with aqueous glycerol solution as substrate Dinitrophenylhydrazone concentration was estimated by absorbance measurements at $544 \mathrm{~nm}$. Experiments were performed in triplicate, and error bars indicate $\mathrm{SD}$.

Table 1 Sensitivity of selected spore-forming bacteria, moulds and yeasts to reuterin

\begin{tabular}{lc}
\hline Species & Sensitivity* \\
\hline Bacillus licheniformis & + \\
Bacillus subtilis & + \\
Bacillus pumilus & + \\
Clostridium tyrobutyricum & + \\
Clostridium sporogenes & + \\
Penicillium sp. & + \\
Candida sp. & + \\
Kluyveromyces sp. & + \\
* Sensitivity expressed as positive when inhibition halo $>2 \mathrm{~mm}$.
\end{tabular}

\section{Reuterin production from biodiesel-derived glycerol}

The synthesis of reuterin involves two main steps: the uptake of glycerol into the cell, followed by the intracellular conversion of this substrate into 3 hydroxypropionialdheyde, mediated by the enzyme glycerol dehydratase. The impurities present in crude glycerol can affect the physiology of $L$. reuteri, altering the amounts of glycerol incorporated and reuterin synthesized. The expression of endogenous glycerol uptake facilitating proteins of the microorganism itself can also limit glycerol entrance to the cell (Lindlbauer $\boldsymbol{e}$ al., 2017). The possibility of using crude glycerol as a substrate depends on the degree of its purity (Samul $\boldsymbol{e t}$ al., 2014). Therefore, to test the feasibility of this work hypothesis, ability of selected strains to effectively produce reuterin from crude and partially purified biodiesel-derived glycerol as a substrate was evaluated. Bioconversion of biodiesel-derived crude glycerol was performed by substituting the aqueous glycerol solution for crude and partially purified biodiesel glycerol. L. reuteri DSM 17938 and isolates SO23 y SO8 produced reuterin from crude $(50 \% \mathrm{w} / \mathrm{w}$ glycerol) and partially purified $(70 \% \mathrm{w} / \mathrm{w}$ glycerol) biodiesel-derived glycerol as substrate (Figure 4). Strain SO8 exhibited the lowest levels of reuterin production under all conditions tested $(\mathrm{P}<0,05) . L$. reuteri DSM 17938 and SO23 behaved similarly with comparable levels of reuterin production for all substrates $(\mathrm{P}=0,14)$. Crude glycerol yielded the lowest reuterin levels for all three strains. The production of reuterin from crude and from partially purified biodiesel-derived glycerol did not exhibit significant differences for isolate SO8 and for the strain DSM 17938 of L. reuteri $(\mathrm{P}>0,05)$, Levels of dinitrophenylhydrazone detected when partially purified glycerol or aqueous glycerol solution were use for the incubation, were similar for isolate SO23 and for $L$. reuteri DSM17938. Impurities like free fatty acid, inorganic salts, and alcohol are present in higher amount in this substrate and that can limit the efficiency of microbial bioconversion (Samul et al., 2014). The impurities had a different impact in each organism tested. Available glycerol concentrations ranging from $150 \mathrm{mM}$ to $400 \mathrm{mM}$ are reported as optimal for reuterin production (Gou et al., 2011; Doleyres et al., 2005). The experiments developed in this work were designed adjusting the concentration of available glycerol to $250 \mathrm{mM}$. 


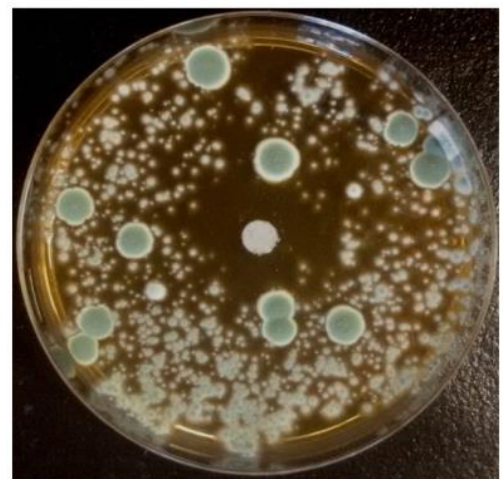

Figure 3 Inhibitory activity of $L$. reuteri SO23 cell-free supernatant against sorghum silage homogenizate containing natural occuring moulds and yeasts.

Like all microbial processes, the bioconversion of glycerol to reuterin is a dynamic process that depends on or can be affected by several factors, like glycerol concentration and purity, $\mathrm{pH}$ and temperature. In addition to the genetic background or the intrinsic enzymatic capacity of each $L$. reuteri isolate studied in this work, the quality of glycerol available for the bioconversion process affected the amount of reuterin produced. An important issue is that crude materials, like biodiesel-derived glycerol, have unstandarized composition and diverse quality depending on raw materials and the industrial process. Isolation and selection of microorganisms able to effectively use wastes or industrial byproducts is a main issue faced for those interested in introducing such processes into biotechnological applications.

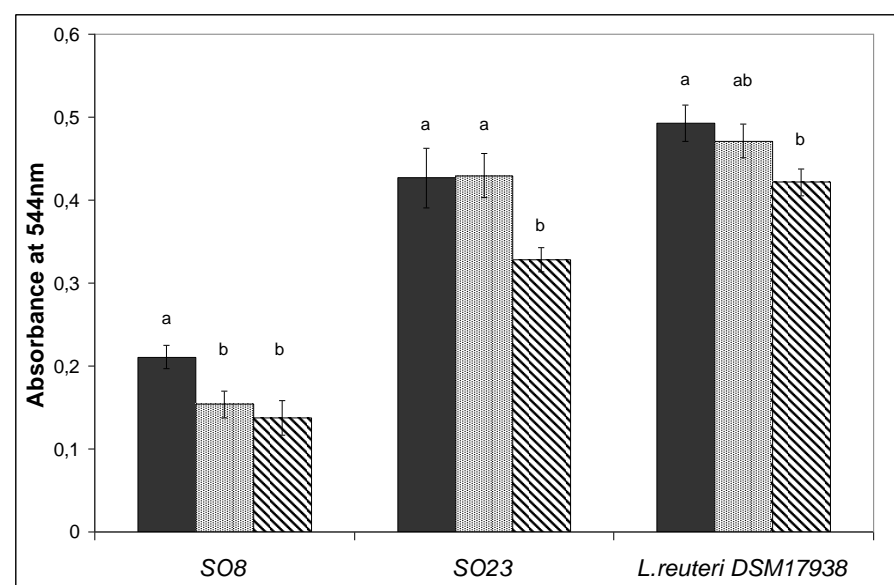

- Aqueous glycerol solution $⿴$ Partially purified biodiesel glycerol $\$$ Crude biodiesel glycerol

Figure 4 Reuterin production from biodiesel-derived glycerol compared to aqueous glycerol solution. Reuterin content in cell-free supernatants was estimated by the production of dinitrophenylhydrazone $\left(\mathrm{A}_{544} \mathrm{~nm}\right)$. Experiments were performed in triplicate, and error bars indicate $\pm \mathrm{SD}$. For each isolate, different letters means significant differences between substrates $(\mathrm{P}<0,05)$.

\section{CONCLUSIONS}

In this work, the production of compounds with carbonyl groups, presumptively reuterin, by two isolates of $L$. reuteri recovered from sorghum silage, is presented. In addition, one of these isolates, L. reuteri $\mathrm{SO} 23$, produced reuterin from biodiesel-derived glycerol at similar levels to those achieved when it was incubated in the presence of pure glycerol. The inhibitory action of reuterin against most common silage spoilage microorganisms and some of the properties displayed by $L$. reuteri SO23 make it very attractive as a potential silage biopreservant inoculant. More research need to be done for the effective use of these reuterin-producing $L$. reuteri isolates as silage biopreservants, but results observed in this study are encouraging. The approach presented could generate an eco-friendly route for the use of a by-product as biodiesel derived glycerol. Also, this represents an opportunity to integrate crude glycerol, and reuterin-producing Lactobacillus spp. in a suitable combination to control silage spoilage microoganisms.

Acknowledgment: The authors acknowledge biodiesel-derived glycerol supply from ALUR Alcoholes del Uruguay (Montevideo, Uruguay).

\section{REFERENCES}

ARQUÉS, J. L., FERNÁNDEZ, J., GAYA, P., NUÑEZ, M., RODRÍGUEZ, E., MEDINA, M. 2004. Antimicrobial activity of reuterin in combination with nisin against food-borne pathogens. International Journal of Food Microbiology 95(2), 225-229. https://doi.org/10.1016/i.ijfoodmicro.2004.03.009

AXELSSON, L. T., CHUNG, T. C., DOBROGOSZ, W. J., LINDGREN, S. E. 1989. Production of a broad spectrum antimicrobial substance by Lactobacillus reuteri. Microbial ecology in health and disease, 2(2), 131-136. https://doi.org/10.3402/mehd.v2i2.7449

BIAN, L., MOLAN, A. L., MADDOX, I., SHU, Q. 2011. Antimicrobial activity of Lactobacillus reuteri DPC16 supernatants against selected food borne pathogens. World Journal of Microbiology and Biotechnology, 27(4), 991-998. https://doi.org/10.1007/s11274-010-0543-z

BURGE, G., SAULOU-BERION, C., MOUSSA, M., POLlET, B., FLOURAT, A., ALLAIS, F., ... SPINNLER, H. E. 2015. Diversity of Lactobacillus reuter strains in converting glycerol into 3-hydroxypropionic acid. Applied biochemistry and biotechnology, 177(4), 923-939. https://doi.org/10.1007/s12010-015-1787-8 CLAISSE, O., LONVAUD-FUNEL, A. 2000. Assimilation of glycerol by a strain of Lactobacillus collinoides isolated from cider. Food Microbiology, 17(5), 513-519. https://doi.org/10.1006/fmic.2000.0342

CLEUSIX, V., LACROIX, C., VOLLENWEIDER, S., DUBOUX, M., LE BLAY, G. 2007. Inhibitory activity spectrum of reuterin produced by Lactobacillus reuteri against intestinal bacteria. BMC Microbiology, 7, 101 https://doi.org/10.1186/1471-2180-7-101

DISHISHA, T., PEREYRA, L. P., PYO, S. H., BRITTON, R. A., HATTIKAUL, R. 2014. Flux analysis of the Lactobacillus reuteri propanediolutilization pathway for production of 3-hydroxypropionaldehyde, 3 hydroxypropionic acid and 1, 3-propanediol from glycerol. Microbial cell factories, 13(1), 76. https://doi.org/10.1186/1475-2859-13-76

DOBSON, R., GRAY, V., RUMBOLD, K. 2012. Microbial utilization of crude glycerol for the production of value-added products. Journal of industria microbiology \& biotechnology, 39(2), 217-226. https://doi.org/10.1007/s10295 011-1038-0

DOLEYRES, Y., BECK, P., VOLLENWEIDER, S., LACROIX, C. 2005 Production of 3-hydroxypropionaldehyde using a two-step process with Lactobacillus reuteri. Applied Microbiology and Biotechnology, 68(4), 467-474. https://doi.org/10.1007/s00253-005-1895-4

DUNIERE, L., SINDOU, J., CHAUCHEYRAS-DURAND, F., CHEVALLIER, I., THÉVENOT-SERGENTET, D. 2013. Silage processing and strategies to prevent persistence of undesirable microorganisms. Animal Feed Science and Technology, 182 (1-4), 1-15. https://doi.org/10.1016/j.anifeedsci.2013.04.006

EL-ZINEY, M. G., DEBEVERE, J. M. 1998. The effect of reuterin on Listeria monocytogenes and Escherichia coli O157: $\mathrm{H} 7$ in milk and cottage cheese. Journal of Food Protection, 61(10), 1275-1280. https://doi.org/10.4315/0362 $\underline{028 \mathrm{x}-61.10 .1275}$

GÓMEZ-TORRES, N., ÁVILA, M., GAYA, P., GARDE, S. 2014. Prevention of late blowing defect by reuterin produced in cheese by a Lactobacillus reuter adjunct. Food Microbiology, 42, 82-88. https://doi.org/10.1016/i.fm.2014.02.018 GUO, C., DAOMAO, Y., YAQIN, X., HONGWEN, C. 2011. Influence of conditions on reuterin accumulation by the resting cell biotransformation process Chinese Journal of Chemical Engineering, 19(6), 1023-1027. https://doi.org/10.1016/s1004-9541(11)60086-4

LANGA, S., LANDETE, J. M., MARTÍN-CABREJAS, I., RODRÍGUEZ, E. ARQUÉS, J. L., MEDINA, M. 2013. In situ reuterin production by Lactobacillus reuteri in dairy products. Food Control, 33(1), 200-206. https://doi.org/10.1016/j.foodcont.2013.02.035

LINDLBAUER, K. A., MARX, H., SAUER, M. 2017. 3Hydroxypropionaldehyde production from crude glycerol by Lactobacillus diolivorans with enhanced glycerol uptake. Biotechnology for biofuels, 10(1), 295. https://doi.org/10.1186/s13068-017-0982-y

LÜTHI-PENG, Q., SCHÄRER, S., PUHAN, Z. 2002. Production and stability of 3-hydroxypropionaldehyde in Lactobacillus reuteri. Applied Microbiology and Biotechnology, 60(1-2), 73-80. https://doi.org/10.1007/s00253-002-1099-0

MARTIN, R., OLIVARES, M., MARIN, M. L., XAUS, J., FERNÁNDEZ, L., RODRÍGUEZ, J. M. 2005. Characterization of a reuterin-producing Lactobacillus coryniformis strain isolated from a goat's milk cheese International Journal of Food Microbiology, 104(3), 267-277. https://doi.org/10.1016/i.ijfoodmicro.2005.03.007

MORITA, H., TOH, H., FUKUDA, S., HORIKAWA, H., OSHIMA, K. SUZUKI, T., ... HATTORI, M. 2008. Comparative genome analysis of Lactobacillus reuteri and Lactobacillus fermentum reveal a genomic island for reuterin and cobalamin production. DNA research, 15(3), 151-161. https://doi.org/10.1093/dnares/dsn009

NAKANISHI, K., TOKUDA, H., ANDO, T., YAJIMA, M., NAKAJIMA, T. TANAKA, O., OHMOMO, S. 2002. Screening of lactic acid bacteria having the ability to produce reuterin. Japanese Journal of Lactic Acid Bacteria, 13(1), 37 45. https://doi.org/10.4109/jslab1997.13.37

PAHLOW, G., MUCK, R. E, DRIEHUIS, F., OUDE ELFERINK, S. J. W. H. SPOELSTRA, S. F. 2003. Microbiology of ensiling. Agronomy, 42, 31-94. https://doi.org/10.2134/agronmonogr42.c2

QUEIROZ, O. C. M., OGUNADE, I. M., WEINBERG, Z., ADESOGAN, A. T 2018. Silage review: Foodborne pathogens in silage and their mitigation by silage 
additives. Journal of Dairy Science, 101(5), $4132-4142$. https://doi.org/10.3168/jds.2017-13901

RIVALDI, J. D., SILVA, M. L. C. S., DUARTE, L. C., FERREIRA, A. E., CORDEIRO, C., DE ALMEIDA FELIPE, M. D. G., ... DE MANCILHA, I. M 2013. Metabolism of biodiesel-derived glycerol in probiotic Lactobacillus strains. Applied Microbiology and Biotechnology, 97(4), 1735-1743 https://doi.org/10.1007/s00253-012-4621-z

SAMUL, D., LEJA, K., GRAJEK, W. 2014. Impurities of crude glycerol and their effect on metabolite production. Annals of microbiology, 64(3), 891-898. https://doi.org/10.1007/s13213-013-0767-x

SAUVAGEOT, N., GOUFFI, K., LAPLACE, J. M., AUFFRAY, Y. 2000. Glycerol metabolism in Lactobacillus collinoides: production of 3hydroxypropionaldehyde, a precursor of acrolein. International Journal of Food Microbiology, 55(1-3), 167-170. https://doi.org/10.1016/s0168-1605(00)00191-4 SCHÜTZ, H., RADLER, F. 1984. Anaerobic reduction of glycerol to propanediol-1,3 by $L$. brevis and L. buchneri. Systematic and Applied Microbiology, 5(2), 169-178. https://doi.org/10.1016/s0723-2020(84)80018-1

SPINLER, J. K., TAWEECHOTIPATR, M., ROGNERUD, C. L., OU, C. N., TUMWASORN, S., VERSALOVIC, J. 2008. Human-derived probiotic Lactobacillus reuteri demonstrate antimicrobial activities targeting diverse enteric bacterial pathogens. Anaerobe, 14(3), 166-171. https://doi.org/10.1016/i.anaerobe.2008.02.001

STELMACHOWSKI, M. 2011. Utilization of glycerol, a by-product of the transesterification process of vegetable oils: a review. Ecological Chemistry And Engineering, $S, 18$ (1), 9-30.

TALARICO, T. L., DOBROGOSZ, W. J. 1989. Chemical characterization of an antimicrobial substance produced by Lactobacillus reuteri. Antimicrobial agents and chemotherapy, 33(5), 674-679. https://doi.org/10.1128/aac.33.5.674

TALARICO, T. L., CASAS, I. A., CHUNG, T. C., DOBROGOSZ, W. J. 1988 Production and isolation of reuterin, a growth inhibitor produced by Lactobacillus reuteri. Antimicrobial agents and chemotherapy, 32(12), 1854 1858. https://doi.org/10.1128/aac.32.12.1854

TANAKA, O., KOMATSU, T., OSHIBE, A., CAI, Y., MIYAZAKI, S., NAKANISHI, K. 2009. Production of 3-hydroxypropionaldehyde in silage inoculated with Lactobacillus coryniformis plus glycerol. Bioscience, $\begin{array}{llll}\text { biotechnology, and biochemistry, } & 73, & 1494-1499\end{array}$ https://doi.org/10.1271/bbb.80863

TOKUYAMA, K., OHNO, S., YOSHIKAWA, K., HIRASAWA, T., TANAKA, S., FURUSAWA, C., SHIMIZU, H. 2014. Increased 3-hydroxypropionic acid production from glycerol, by modification of central metabolism in Escherichia coli. Microbial cell factories, 13(1), 64. https://doi.org/10.1186/1475-2859-13-64 VOLLENWEIDER, S., LACROIX, C. 2004. 3-Hydroxypropionaldehyde: applications and perspectives of biotechnological production. Applied Microbiology and Biotechnology, 64(1), 16-27 https://doi.org/10.1007/s00253003-1497-y

VOLLENWEIDER, S., EVERS, S., ZURBRIGGEN, K., LACROIX, C. 2010. Unraveling the hydroxypropionaldehyde (HPA) system: an active antimicrobial agent against human pathogens. Journal of Agricultural and Food Chemistry, 58(19), 10315-10322. https://doi.org/10.1021/jf1010897

WALTER, J., BRITTON, R. A., ROOS, S. 2011. Host-microbial symbiosis in the vertebrate gastrointestinal tract and the Lactobacillus reuteri paradigm. Proceedings of the National Academy of Sciences, 108(Supplement 1), 46454652. https://doi.org/10.1073/pnas.1000099107

WEISBURG, W.G., BARNS, S.M., PELLETIER, D.A., LANE, D.J. 1991. $16 \mathrm{~S}$ ribosomal DNA amplification for phylogenetic study. Journal of Bacteriology, 173, 697-703. https://doi.org/10.1128/jb.173.2.697-703.1991 